\title{
The effect of Experimental lung lesion on the activity of 5- NT and GGT in plasma of calves
}

\author{
تأثير آفة الرئة التجريبية علي نشاط أنزيمي 5-NT و GGT في بلازما دم العجول
}

\author{
S.E.M.Barakat* \& H.A.Mohamed
}

\section{Summary}

Six Kenana calves between 2 and 4 months old were divided into two groups. Calves in group 1, were orally given DL-tryptophan in doses of $0.5 \mathrm{~g} / \mathrm{kg}$, body weight during the $1^{\text {st }}$ week, $0.6 \mathrm{~g} / \mathrm{kg}$, body weight during the $2^{\text {nd }}$ week, $0.7 \mathrm{~g} / \mathrm{kg}$, body weight during the $3^{\text {rd }}$ week, and $1 \mathrm{~g} / \mathrm{kg}$ during the $4^{\text {th }}$ week. Calves in group2, were dosed with L-tryptophan in the same maner as described for group 1 calves. It has been shown that DL-tryptophan or L-tryptophan given to young Kenana calves in single or repeated doses produced a very mild pulmonary lesion. The activity of 5-NT, SD and GD and concentration of urea in plasma of calves in both groups showed no change after dosing with tryptophan. Whereas the activity of GGT in plasma of all calves showed progressive increase after dosing.

الخلاصة:

وضعت ستة عجول من نوع الكنانة يتراوح عمرها ما بين شهرين الي أربعة أثشر في مجموعتين

• منفصلتين

المجموعة الأولى تم تجريعها مادة (تربتوفان-DL) بجرعة فموية ه . •جم لكل كيلوجرام من وزن الجسم

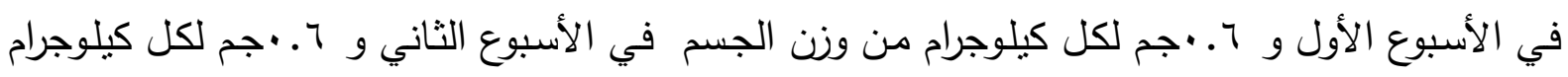
من وزن الجسم في الأسبوع الثالث وواحد جم لكل كيلوجرام من وزن الجسم في الأسبوع الرابع.

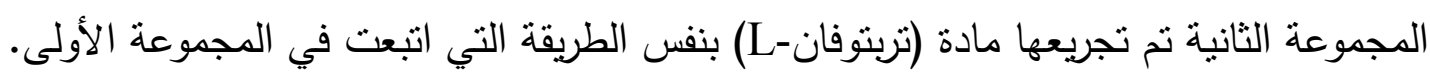

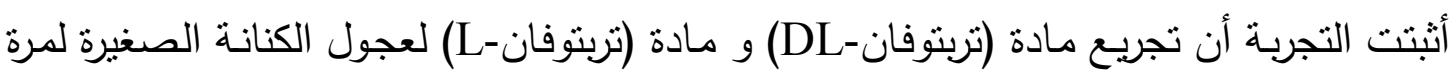

واحدة أو لمرات متعددة تحدث آفه رئوية ثانوية محدودة الأثر.

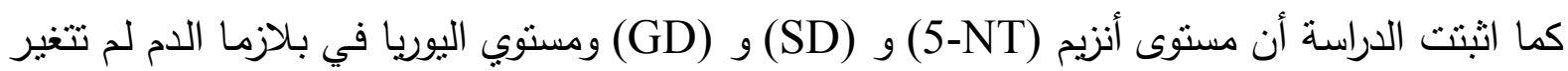

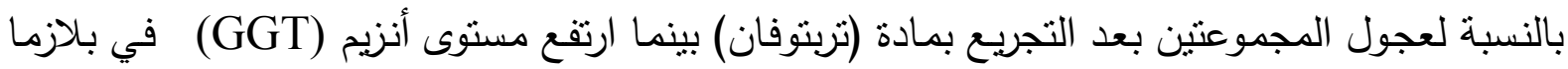
الدم بالنسبة لكل العجول بصورة تصاعدية بعد تجريعها بمادة (تربتوفان).

* Sudan University of Science and Technology

College of Veterinary Medicine and Animal Production

Khartoum North P. O. Box 204 


\section{1- INTRODUCTION}

Many workers have observed the development of an acute respiratory distress syndrome (ARDS) in cattle after an abrupt change from poor to lush pasture (Selman, et.al. 1976; Selman et.al.1977). Others have associated the development of the respiratory syndrome with the presence of the amino acid tryptophan in many green plants used as animal feeds (Brady 1973, Mackenzie, et.al. 1975). Experimental studies have shown that cattle develop an acute respiratory distress syndrome (ARDS) after oral administration of the amino acid DL tryptophan (Carlson \& Dickinson 1978). 3-methyle indole (3-MI) is an important pneumotoxic metabolite of tryptophan produced in the rumen (Carlson et.al 1975; Pirie 1976).

Confusion in the terminology used to describe normal and abnormal lung sounds exists even in man (Roundebush 1982). In modern veterinary hospitals using thoracic radiographs is of value in detecting chronic coughing due to pleural effusion and mediastinal mass, (Radostits et al., 2000, Cowgil \& Neel 2003). Methods of precisely diagnosing pulmonary damage and its severity would be of value to both veterinary practitioners and research workers. It has been shown that the lungs of cattle and sheep are the richest sources of the enzyme 5-NT and GGT (Barakat \& Ford 1988). Cellular and molecular studies in rats lung have shown that GGT gene is expressed in distal lung epithelium and that enzyma tically active GGT protein is present in lung surfactant, (Joyce-Brady et al 1994. Takahashi, et al. 1997). 
As enzymes tend to leak into plasma mainly from damaged tissues with high enzyme content, the enzymes 5-NT and GGT could be of diagnostic value in detecting pulmonary damage.

The present experiments were designed to determine the value of plasma 5-NT, GGT and other plasma constituents as potential indicators of the severity of pulmonary damage.

\section{2- MATERIALS AND METHODS}

\section{1- Animals}

Six Kenana calves between 2 and 4 months old weighing between 25 and $96 \mathrm{~kg}$ were divided into two groups and housed in individual pens. They were fed on 2-3 kg of calf nuts per day with free access to hay and water. Calves Nos.471, 2697, and 2710 group 1, were given DL-tryptophan via a stomach tube in aqueous suspension in doses of $0.5 \mathrm{~g} / \mathrm{kg}$ body weight during the $1^{\text {st }}$ week, $0.6 \mathrm{~g} / \mathrm{kg}$ body weight during the $2^{\text {nd }}$ week, $0.7 \mathrm{~g} / \mathrm{kg}$ body weight during the $3^{\text {rd }}$ week and $1 \mathrm{~g} / \mathrm{kg}$ body weight during the $4^{\text {th }}$ week. The number of doses and the total amount of DL-tryptophan given are shown in table.I. Calves (Nos.476, 677 and 700) group 2, were dosed as indicated in table 2 with L-tryptophan via a stomach tube as an aqueous suspension in the same manner as described for group 1 calves.

The development of a lung lesion was assessed by daily auscultation of the chest and measurements of body temperature, pulse rate and respiratory rate. One calf from group 2 No. 476 died immediatly after dosing with L-tryptohan No.677 was killed after 4 weeks for postmortem examination and histological examination of lung and other organs. 
Blood samples were collected from all calves on numerous occasions before and after dosing to study changes in the activities of 5-NT, GGT, SD, GD and the concentration of urea in plasma

\section{2- Histological methods}

Portions of the lung samples collected after postmortem of experimental animals were immediately fixed in $10 \%$ buffered formalsaline and blocked in paraffin wax. $5 \mu$ thick sections were stained by haematoxylin and eosin (H \& E), using Mayer's haemalum.

\section{3- Analysis of plasma}

The activity of GGT in plasma was measured with a test combination (Boehringer, Mannheim) according to the method of Szasz (1969).

5-NT activity in plasma was measured with an assay kit (BDH chemicals 1td. Poole) based on the method of Persijn et.al (1970).

The activities of Sorbitol dehydrogenase (SD) and Glutamate dehydrogenase (GD) in plasma were measured by commercial kits (Plasmatic Labortory Products LTD, England).

The concentration of urea in plasma was measured by commercial kits (Roche Products, Herts, UK) based on the method described by Tietz (1987). 


\section{3- Results}

\section{3-1 Clinical signs}

Calves in group 1 (Nos. 471, $2697 \&$ 2710) which had been given Dl-tryptophan showed an increase in respiratory rate (tachypnoea) (range 20-41/min) as shown in Fig. I. On auscultation, inspiratory and expiratory sounds were normal. There was no change in heart rate or body temperature. Appetite of all calves was normal following dosing with DL-tryptophan. Calves in groups 2 (Nos. $677 \&$ 700) which were given L-tryptophan showed a small increase in respiratory rate (range $22-46 / \mathrm{min}$ ) as shown in Fig. I. although dyspnoea was not noted. Occasional coughing, an irregular increase in heart rate and normal body temperature were observed in both calves. On auscultation, inspiratory and expiratory sounds were sometimes harsh. A disagreeable odur was emitted from both calves after dosing with L-tryptophan. Animal No. 677 which showed inappetence and dullness was killed after 4 weeks. At necropsy, the lung was pale and spongy without evidence of congestion, oedema, or emphysema. All other organs were normal.

\section{3-2 Histological findings:}

The lung parenchyma of calf No. 677 (Fig 46) was well aerated, without evidence of oedema or inflammation. There was patchy partial collapse and a moderate amount of bronchus associated lymphoid tissue usually in the form of small follicles without germinal centres. A few neutrophilic leucocytes were seen in the bronchial epithelium, subepithelial connective tissue and lumina of bronchial glands. 


\section{3-3 Changes in plasma constituents:}

Fig. 3 shows that there was no change in the mean activities of 5-NT, SD, GD, and in the mean concentration of urea, but a slight increase in the mean activity of GGT in plasma of calves Nos. 471, 2697, and 2710 (group 1). Similarly Fig. 4 shows no change in the mean activities of 5-NT, SD, GD, and in the mean concentration of urea, but a moderate increase in the mean activity of GGT in plasma of calves Nos. 677 and 700 (group 2). The activity of GGT in all calves started to increase slowly and progressively, and reached highest values during the 4 th week of the experiment.

The increase in GGT activity in plasma seems to be roughly related to the amount of DL-tryptophan or L-tryptophan given. 


\section{Table 1}

Schedule of dosing with DL-tryptophan of calves of group 1

\begin{tabular}{|c|c|c|c|c|c|c|}
\hline $\begin{array}{l}\text { Time and } \\
\text { Dose rate }\end{array}$ & Calf No. & Sex & $\begin{array}{c}\text { Weight } \\
\text { (kg) }\end{array}$ & Dose (g) & $\begin{array}{c}\text { No. of } \\
\text { Doses per } \\
\text { week }\end{array}$ & $\begin{array}{c}\text { Total } \\
\text { Dose (g) }\end{array}$ \\
\hline \multirow{3}{*}{$\begin{array}{l}1^{\text {st }} \text { week } \\
(0.5 \mathrm{~g} / \mathrm{kg})\end{array}$} & 471 & $\mathrm{M}$ & 80 & 40 & 3 & 120 \\
\hline & 2697 & $\mathrm{~F}$ & 45 & 22.5 & 3 & 67.5 \\
\hline & 2710 & $\mathrm{~F}$ & 25 & 12.5 & 3 & 37.5 \\
\hline \multirow{3}{*}{$\begin{array}{l}2^{\text {nd }} \text { week } \\
(0.6 \mathrm{~g} / \mathrm{kg})\end{array}$} & 471 & $\mathrm{M}$ & 84.5 & 50.7 & 3 & 152.1 \\
\hline & 2697 & $\mathrm{~F}$ & 49 & 29.4 & 3 & 88.2 \\
\hline & 2710 & $\mathrm{~F}$ & 28 & 16.8 & 3 & 50.4 \\
\hline \multirow{3}{*}{$\begin{array}{l}3^{\text {rd }} \text { week } \\
(0.7 \mathrm{~g} / \mathrm{kg})\end{array}$} & 471 & $\mathrm{M}$ & 91 & 63.7 & 3 & 191.1 \\
\hline & 2697 & $\mathrm{~F}$ & 53.5 & 37.5 & 3 & 112.5 \\
\hline & 2710 & $\mathrm{~F}$ & 32 & 22.4 & 3 & 67.2 \\
\hline \multirow{3}{*}{$\begin{array}{c}4^{\text {th }} \text { week } \\
(1 \mathrm{~g} / \mathrm{kg})\end{array}$} & 471 & $\mathrm{M}$ & 96.5 & 96.5 & 3 & 289.5 \\
\hline & 2697 & $\mathrm{~F}$ & 57 & 57 & 3 & 171 \\
\hline & 2710 & $\mathrm{~F}$ & 35 & 35 & 3 & 105 \\
\hline
\end{tabular}


Table 2:

Schedule of dosing with L-tryptophan of calves of group 2

\begin{tabular}{|c|c|c|c|c|c|c|}
\hline $\begin{array}{l}\text { Time and } \\
\text { Dose rate }\end{array}$ & Calf No. & Sex & $\begin{array}{c}\text { Weight } \\
\text { (kg) }\end{array}$ & Dose (g) & $\begin{array}{c}\text { No. of } \\
\text { Doses per } \\
\text { week }\end{array}$ & $\begin{array}{c}\text { Total } \\
\text { Dose (g) }\end{array}$ \\
\hline $1^{\text {st }}$ week & 677 & $\mathrm{M}$ & 68 & 34 & 3 & 102 \\
\hline$(0.5 \mathrm{~g} / \mathrm{kg})$ & 700 & M & 70 & 35 & 3 & 105 \\
\hline $2^{\text {nd }}$ week & 677 & $\mathrm{M}$ & 72.5 & 43.5 & 3 & 130.5 \\
\hline$(0.6 \mathrm{~g} / \mathrm{kg})$ & 700 & M & 75 & 45 & 3 & 135 \\
\hline $3^{\text {rd }}$ week & 677 & M & 78 & 54.6 & 3 & 163.8 \\
\hline$(0.7 \mathrm{~g} / \mathrm{kg})$ & 700 & M & 80.5 & 56.4 & 3 & 169 \\
\hline $4^{\text {th }}$ week & 677 & $\mathrm{M}$ & 83 & 83 & 3 & 249 \\
\hline$(1 \mathrm{~g} / \mathrm{kg})$ & 700 & M & 86 & 86 & 3 & 258 \\
\hline
\end{tabular}




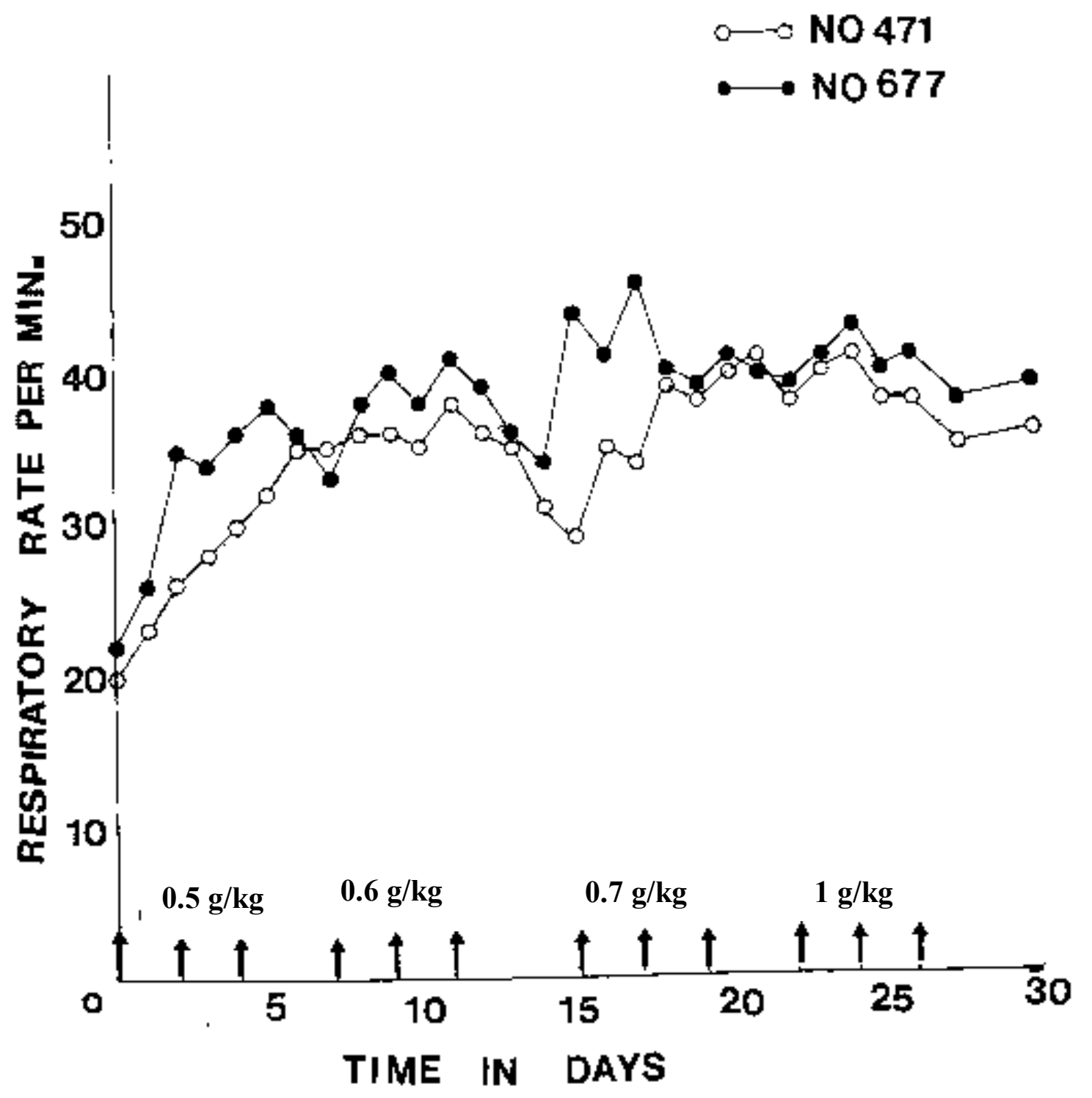

Fig. 1- Respiratory rates of calf No. 471 given L-tryptophan at times and dose rates indicated by the arrows. 


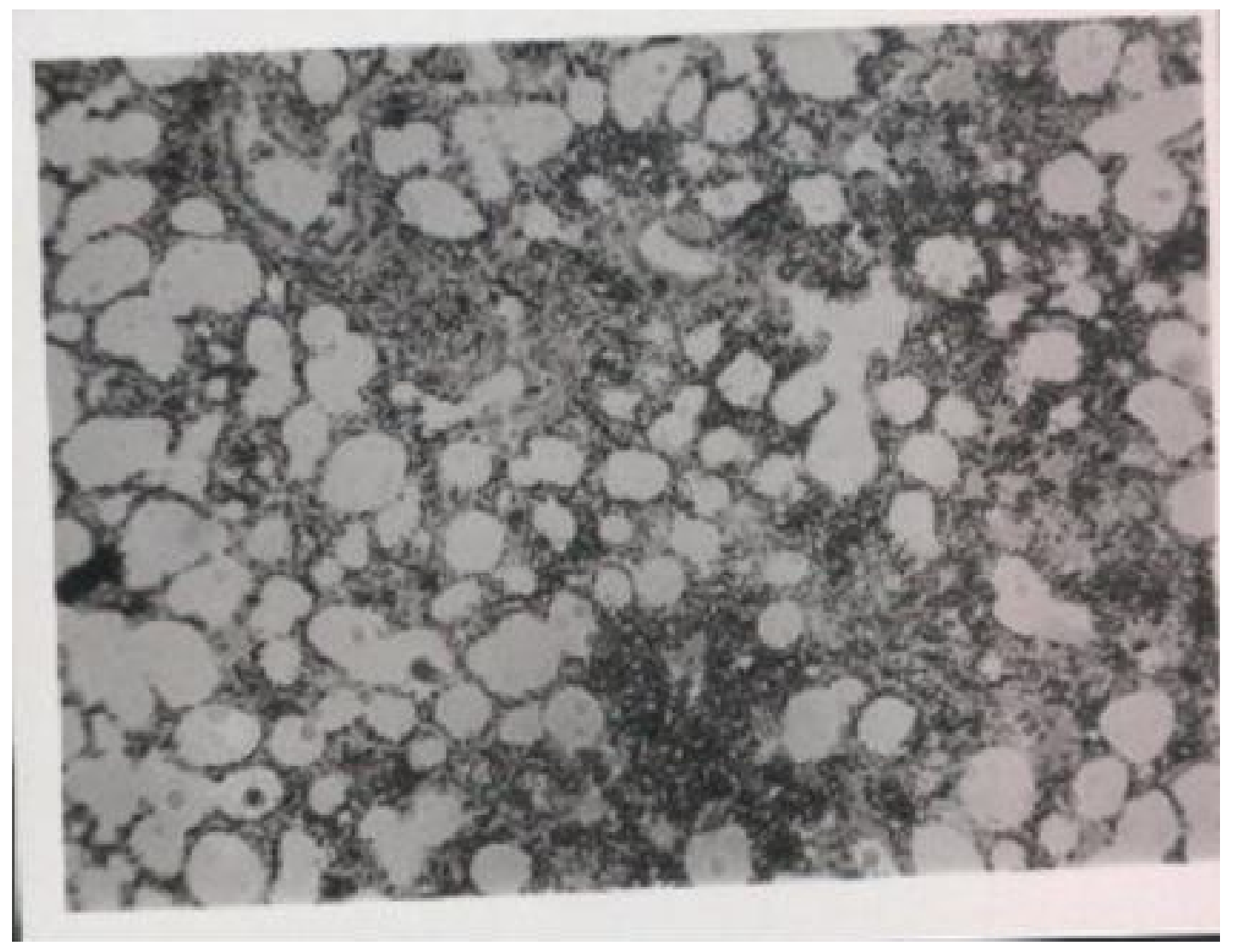

Figure (2). Lung of Calf No. 677 showing patchy partial collapse and bronchus associated lymphoid tissue $\mathrm{H} \& \mathrm{E} \mathrm{x}$ 

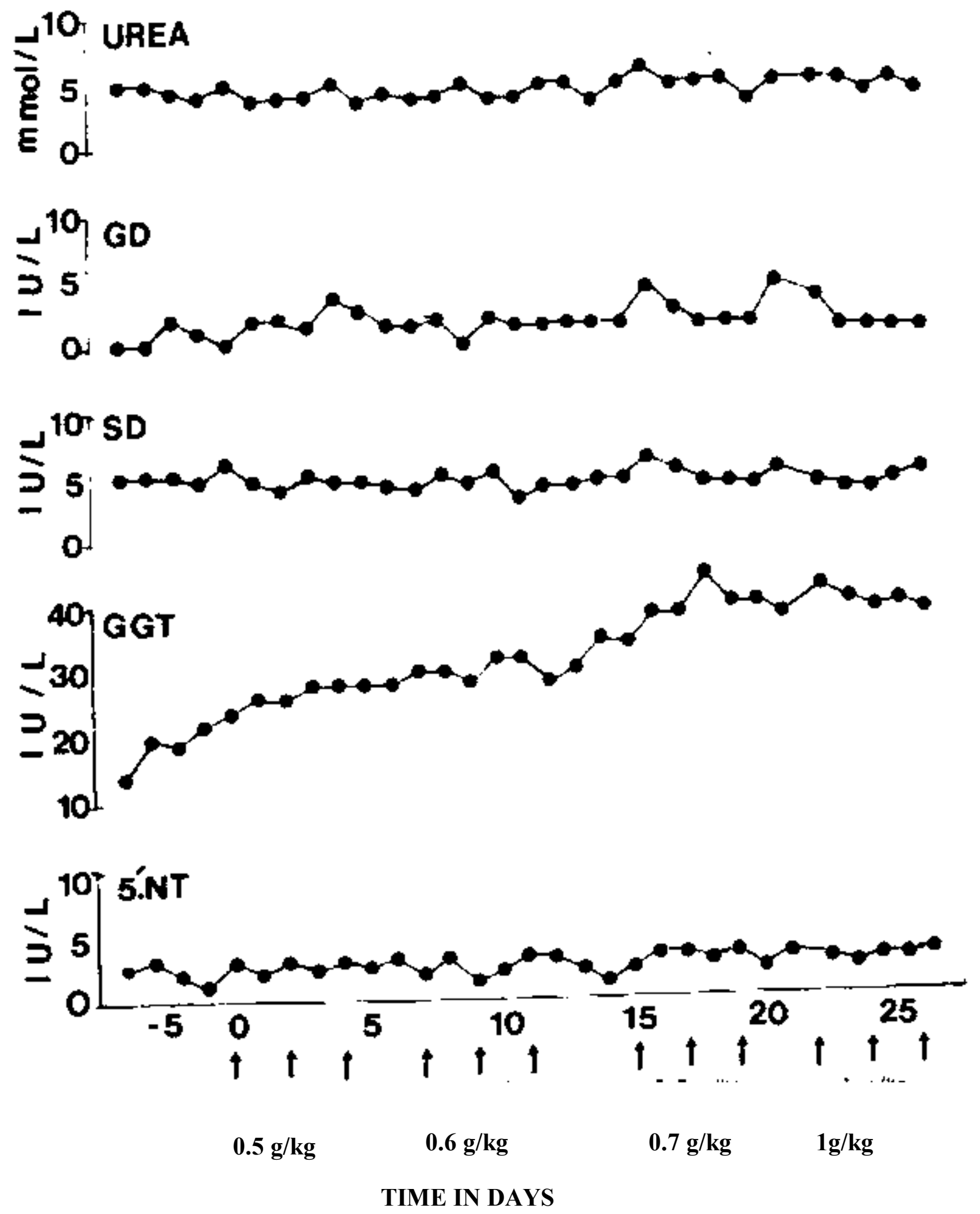

Fig. 3- Mean activity of 5.NT, GGT, SD, GD and concentration of urea in plasma in calves Nos. 471, $2697 \& 2710$, which were given DL-tryptophan orally at times and dose marked by the arrows. 

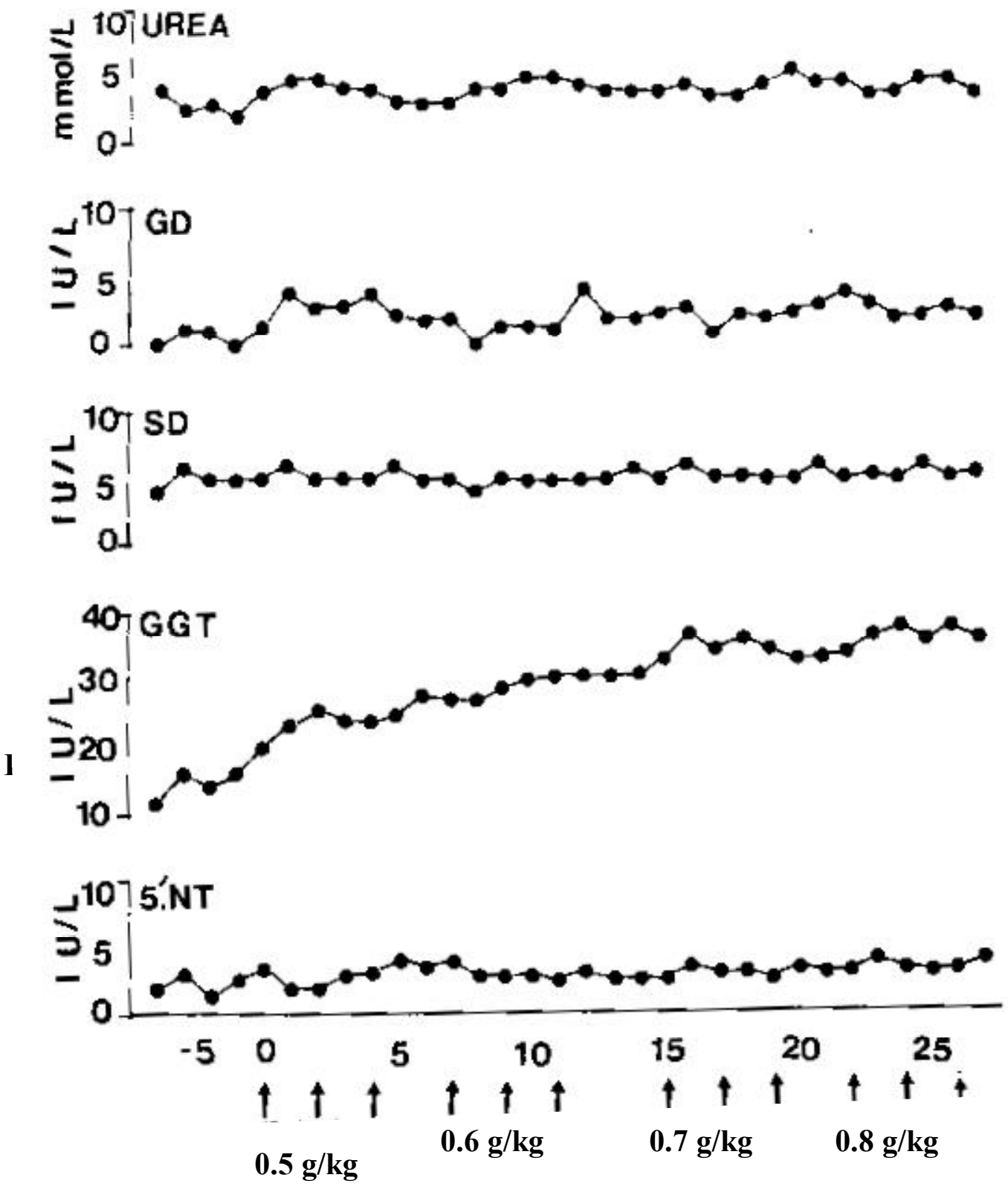

\section{TIME IN DAYS}

Fig. 4- Mean activity of 5.NT, GGT, SD, GD and concentration of urea in plasma in calves Nos. $677 \& 700$ which were given L-tryptophan orally at times and dose marked by the arrows. 


\section{4-DISCUSSION}

The present experiments have shown that DL-tryptophan or L tryptophan given to young calves in single or repeated doses produced a very mild pulmonary lesion reflected by small increase in respiratory rate. The susceptibility of cattle to tryptophan toxicity seems to be influenced by many factors, Selman, et.al (1974).

Calf No 476 (group 2) which died immediately after dosing with DL-tryptophan showed residues of DL- tryptophan suspension in lung tissue. It is assumed that death is due to suffocation.

The disagreeable odour which was emited from calves Nos.677 and 700 ( group 2) after dosing with L- tryptophan may be due to the formation of 3-methyl indole. Yokoyama and Carlson (1974) suggested that ruminal degradation of L- tryptophan leads to the formation of indole acetic acid (IAA) which is then converted to 3-methyle indole.

The histological appearance of the lung of calf No. 677 was that of mild chronic active bronchitis.

Failure of the activity of 5- NT to increase in the plasma of all calves after dosing with both types of tryptophan may be due to the fact that the damage to the lung was not sufficiently severe to release the enzyme into the blood.

The release of cellular enzymes into plasma can be affected by the route of access of cell proteins to circulating plasma. Thus many of the cells in the kidneys and lung are in contact with an external body surface and when the cells are damged enzyme leaks into renal tubules in case of kidneys or alveolar spaces in case of the lungs (Donald et.al. 1987). Little is known about the way in which enzymes are cleared from the circulation. The half-life $\left(\mathrm{t}^{1} / 2\right)$ of an enzyme in plasma may be a few 
hours or several days, Donald et.al.(1987). The failure of the activity of $\mathrm{SD}$ and GD to increase in the plasma of calves after dosing with tryptophan may be due to their low content in the lungs of all mammalian species, (Clampit and Hart 1978, Barakat \& Ford 1988) The progressive increase in the activity of GGT in plasma of all calves after dosing with tryptophan may be due to lung damage. Damage of the kidney may also contribute to increase in GGT, as it has been shown that the major metabolite of tryptophan is 3-methyle indole, a substance which is capable of causing haemolysis and haemoglobinuric nephrosis in cattle, Hammond et.al. (1980). 


\section{REFERENCES}

Barakat, S.E.M. and Ford, E.J.H., (1988). Further studies on the diagnostic value of GGT and 5-NT in cattle, sheep, and horses. Res. Vet. Sci. 44, 354-360.

Brady, C.J. (1973). Chemistry and biochemistry of Herbage. Vol.2., Editors Butlors, G.W. and Bailey, R.W. Academic press, London and New York.

Carlson, J.R. and Dickinson, E.O., (1978). Tryptophan induced pulmonary oedema and emphysema in ruminants in "Effects of poisonous plants on livestock" Edited by: Keeler, R.F., Vankampen, K.P. and James, L.F., Academic Press, New York, San Francisco. (pp 261-271).

Carlson, J.R., Dickinson, E.O., Yokoyama, M.T. and Bradley, B.J., (1975). Pulmonary oedema in cattle after intra ruminal and intravenous doses of 3- Methyle Indole. Am. J. Vet Res. 36, 1341-1347.

Clampitt, R.B. and Hart, R.J., (1978). The tissue activities of some diagnostic enzymes in ten mammalian species. J. Comp. path. $\underline{88}$, 607-621.

Cowgil, E. and Neel J., (2003). Pleural fluid from a dog with marked eosinophilia. Vet. Clin.Pathol.32, No 3, 147-149.

Donald, W., Moss, A., Ralph, H. John, F. (Enzymes) - Fundamentals of clinical chemistry $3^{\text {rd }}$ Edition W.B. Saunders company. Philadelphia, London, Toronto. Page 346-414.

Hammond, A.C., Bradley, B.J. and Breeze, R.C., (1980). Prevention of tryptophaninduced acute bovine pulmonary oedema and emphysema (fog fever). Vet. Rec. $\underline{107}$, 322-325.

Joyce- Brady, M., Takahashi, Y., Oakes, S.M., Rishi, A.K, Levine, R.A., Kinglough, C.L. and Hughey., (1994). Synthesis and release of amphipathic GGT by pulmonary alveolar type 2 cells. J. Biol. Chem 269, 14219- 14226 
Mackenzie, A., Ford, J. E and Scott, K.J., (1975). Pasture levels of tryptophan in relation to outbreaks of fog fever. Res. Vet. Sci 19, 277-228.

Persijin, J.P., Vandersilk, W., Bon A.W.M., (1970). A new method for the determination of serum nucleotidase. Kliniche chemica Kliniche Biochemica 7, 493-497.

Pirie, H.M., Breeze R.G., Selman, I.E., and wiseman, A., (1976). Indole acetic acid, 3methyle indole and type 2 pneumocytes hyperplasia in proliferative alveolitis in cattle. Vet. Rec. $\underline{98}, 259-260$.

Radostits, O.M., Gray, C.C., Blood, D.C. and Hinchcliff, K.W., (2000). Veterinary medicine, W.B. Saunders company Ltd.

Roundebush, P. (1982). Lung sounds . J. Am. Vet. Med. Ass. 181, 122-126

Selman, I.E., Breeze, R.G., Bogan, J.A., Wiseman, A. and Pirie, H.M. (1977) Experimental production of fog fever by change to pasture free from Dectyocaulus viviparous infection. Vet. Rec.101, 278-283.

Selman, I.E., Wiseman, A., Pirie, H.M. and Breeze, R.G. (1974). Fog fever in cattle: various theories on its aetiology

Szasz, G. (1969). L-Y- Glutamyle transferase:- Colorometric method, clin. Chem. 15, 124136.

Takahashi, Y., Oakes, S.M., Williams, M.C., Takahashi, S., Miura, T. and Joyce- Brady, M., (1997). Nitrogen dioxide exposure activates gamma- glutamyle transferase gene expression in rat lung. Toxicol. App. Pharmacol.143 (2), 388-96. 